\title{
Evaluation of Attitudes and Behavioral Changes in Relatives of Patients with Breast Cancer
}

\author{
(DDPınar Döner Güner ${ }^{1}$ (ID) Hilal Aksoy², (DD) Hande Bölükbaşı, ${ }^{3}$ (iD) İsa Dede ${ }^{4}$ \\ ${ }^{1}$ Asst. Prof., Hatay Mustafa Kemal University Faculty of Medicine, Family Medicine Department, Hatay, Turkey \\ ${ }^{2}$ M.D. Spec., Hacettepe University Faculty of Medicine, Department of Family Medicine, Ankara, Turkey \\ ${ }^{3}$ M.D. Spec., Hatay Mustafa Kemal University Faculty of Medicine, Family Medicine Department, Hatay, Turkey \\ ${ }^{4}$ Asst. Prof., Hatay Mustafa Kemal University Faculty of Medicine, Department of Internel Medicine, Medical Oncology Division, \\ Hatay, Turkey
}

$\ddot{0} z$

\section{Yakınlarında Meme Kanseri Bulunan Kișilerde Tutum ve Davranıș Değișikliklerinin Değerlendirilmesi}

Amaç: Bu çalıșmanın amacı yakınlarında meme kanseri bulunan kișilerin bilgi ve destek ihtiyaçlarının ne ölçüde karșılandığını belirlemektir.

Yöntem: Bu kesitsel tanımlayıcı çalıșma, Mayıs-Eylül 2019 tarihleri arasında Onkoloji Bilim Dalı'nda yakınları meme kanseri tanısı ile izlenen 177 katılımcı ile gerçekleștirilmiştir. Katılımcılara anket ve sosyodemografik özellikler ile "Bilgi ve Destek İhtiyaçları Ölçeği" uygulanmıștır.

Bulgular: Katılımcıların ortalama yaşı 39,70 \pm 14,10 idi. 66'sı (\% 37,30) ilkokul mezunu, 106'sı (\% 59,90) ev hanımı ve 124'ü (\% 70,10) evliydi. Kadınlarda en yaygın meme kanseri tarama yöntemleri\% 68,40 (121) ile kendi kendine muayene ve\% 54,20 (96) ile mamografi idi. Meme kanseri taraması yaptıran katılımcı sayısı 78 (\% 44,30) idi. Bilgi gereksinimleri ortalama puanı 3,50 $\pm 0,09$ ve destek gereksinimleri ortalama puanı 3,30 \pm 0,18 idi. İstatistiksel analizler SPSS 21.0 programı ile yapıldı.

Sonuç: Yakın çevresinde meme kanseri olan kadınların meme kanserinin nedenleri, tarama yöntemleri, tedavi yöntemleri ve önlenmesi konusunda sağlık profesyonelleri tarafından bilgi durumlarının, tutumlarının ve ihtiyaçlarının belirlenmesi gerekmektedir. Bu sayede meme kanseri taramasının yaygınlașması sağlanarak erken tanı konulan hasta sayısı artacak ve tedavide daha yüksek bașarı sağlanacaktır. Anahtar Kelimeler: Meme Kanseri, Kendi Kendine Muayene, Bilgi, Destek

\section{Abstract}

Evaluation of Attitudes and Behavioral Changes in Relatives of Patients with Breast Cancer

Objective: The aim of this study was to determine the information and support needs of breast cancer patients' relatives and to what extent they were met.

Methods: This cross-sectional descriptive study was conducted with 177 participants whose relatives were followed up with breast-cancer diagnosis in the Oncology Department between May and September 2019. The questionnaire and sociodemographic characteristics and "Information and Support Needs Scale" were applied to the participants.

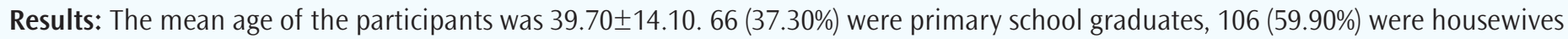
and 124 (70.10\%) were married. The most common breast cancer screening methods for women were 68.40\% (121) self-examination and $54.20 \%$ (96) mammography. The number of participants who had breast cancer screening was 78 (44.30\%). The mean score of information requirements was $3.50 \pm 0.09$ and the mean score of support requirements was $3.30 \pm 0.18$. with Statistical analysis were performed with SPSS 21.0 program.

Conclusion: It is necessary to determine the knowledge status, attitudes and needs of women who have breast cancer in their neighborhood by the health professionals about the causes, screening methods, treatment methods and prevention of breast cancer. In this way, it will increase the spread of breast cancer screening, the number of patients diagnosed early and the success of treatment. Keywords: Breast Cancer, Self-Examination, Information, Support

Nasıl Atıf Yapmalı / How to Cite: Güner PD, Aksoy H, Bölükbașı H, Dede İsa. Evaluation of Attitudes and Behavioral Changes in Relatives of Patients with Breast Cancer. MKÜ Tip Dergisi. 2021;12(43):65-72. https://doi.org/10.17944/mkutfd.893872

Sorumlu Yazar/Corresponding Author: M.D. Spec., Hilal Aksoy

Email: hilal.aksoy35@gmail.com

Geliș/Received: 9 Mart 2021

ORCID iD: 0000-0002-3330-9317 


\section{INTRODUCTION}

Breast cancer is the most common cancer in women and is among the leading causes of cancer-related deaths worldwide $(1,2)$. It is the most common cause of cancer-related death in women in the United States (US) (3). According to GLOBOCAN 2018 data published by the World Health Organization and the International Cancer Agency (IARC-International Agency for Research on Cancer), there were 2.100.000 new breast cancer cases and 627.000 cancer-related deaths. It has been observed that $25 \%$ of cancers in women and $15 \%$ of cancer-related women deaths are because of the breast cancer. In 2018, there were 522.513 new cancer cases in Europe and 234.087 in the US. In Turkey 22.345 new cases of breast cancer were detected as $24.30 \%$ of all cancer cases. Breast cancer is the first in cancer-related deaths and constitutes $13 \%$ of this group with 5452 cases (4). Breast cancer is the second most common cancer diagnosed worldwide, including low and middle income countries (5). Incidence rates are highest in North America, Australia and New Zealand, lowest in Western and Northern Europe, and Asia and Sub-Saharan Africa (2). These international differences are probably associated with social changes as a result of industrialization (for example, changes in fat intake, body weight, age of menarche, breastfeeding, less pregnancy and first birth age). Studies on immigration models to the US are consistent with the importance of cultural and / or environmental changes (3). In the US, breast cancer accounts for more than 260.000 cases each year and is responsible for more than 40.000 deaths (3).

Although the etiology of breast cancer is not fully known, hormonal, environmental and genetic factors are defined as risk factors (6). Female gender, advanced age, having a history of breast cancer in the first-degree relatives, BRCA-1 and BRCA-2 gene mutations are defined as the greater risk factors. In addition, early menarche ( $<12$ years old), late menopause (> 55 years old), age of first birth over 30 years of age, alcohol, smoking, fatty eating and high Body Mass Index (BMI) are also identified as risk factors (7).

Although it increases the success rate of early diagnosis of breast cancer, it prolongs the life span. For this purpose, breast examination and breast examination mammography are recommended by the physician within the scope of screening programs (1). Awareness for breast cancer in women is possible by providing training and consultancy on the importance of early diagnosis and breast cancer screening methods.

A population-based screening, which starts at the age of 40 and ends at age 69, is recommended for the breast cancer target population and screening frequency in women throughout our country. The ideal method is screening with mammography (MG) every two years and clinical breast ex- amination should be performed in every woman who participates in cancer screening in order to increase the effectiveness of mammography. In addition, after the age of 20, every woman should be given counseling to perform breast self-examination (BSE) (8). Additionaly women who have a family history of breast cancer in their first-degree relatives and who do not have a genetic syndrome are at a moderate risk of breast cancer. In other words, there is an approximately 15-20 percent chance of having breast cancer in their lifetime. Therefore, it is important that first-degree relatives are informed about this issue and that they are included in the screening.

This study was carried out to determine the information and support needs of breast cancer patients' relatives and to what extent these needs were met.

\section{MATERIALS AND METHODS}

This cross-sectional descriptive study was carried out in May 2019-September 2019 with relatives of patients diagnosed with breast cancer who were followed and treated at the Hacettepe University Medical Faculty, Oncology Department. A post-consent questionnaire was administered to 177 patients with breast cancer over 18 years old who agreed to participate.

In the survey, sociodemographic characteristics and a number of personal attitudes were questioned and the "Information and Support Requirements Scale" developed in 2001 by Chalmers and colleagues was applied in order to determine the information and support needs of women with first-degree breast cancer (9). The scale has two sub-dimensions. The Importance of Requirements Scale consists of 29 items, 18 items are for information needs and 11 items are for support needs. In this scale, the order of necessity is determined. Requirements Meeting Scale is also used in the Importance of Requirements Scale, but this section determines to what extent the requirements are met. The scales are Likert type and on the Importance of Requirements Scale, "1 = not important", "2 = less important", "3 = somewhat important", " $4=$ very important"; It is evaluated as " $1=$ never met", " 2 = less met", " 3 = slightly met", " 4 = fully met" in the Requirements Meeting Scale. In addition, since each item is not applicable for all participants, there is also the option " $0=$ not applicable". Firstly, women chose the importance of information and support needs and to what extent they were met. The total score is not obtained from the scales, the average score for each item is determined. So "importance of requirements " and "meeting the requirements " are prioritized due to scores.

\section{Statistical analysis}

The data obtained were evaluated with SPSS 21.0 program. The relationship between categorical variables was evaluated 
by Chi-Square and Fisher's exact test, the relationship between continuous variables was evaluated by Mann-Whitney U test and Kruskal Wallis Students' t test. The relationship between continuous variables was evaluated with the Spearman correlation test. $\mathrm{p}<0.05$ was considered significant.

Table 1. Sociodemographic Characteristics of the Participants ( $n$ : 177).

\begin{tabular}{|l|c|}
\hline \multicolumn{1}{c|}{ Features } & Mean \pm SD \\
\hline Age & $39.75 \pm 14.10$ \\
\hline Size & $163.75 \pm 6.13$ \\
\hline Weight & $67.31 \pm 12.27$ \\
\hline BMI & $25.17 \pm 4.84$ \\
\hline Age of menarche & $12.81 \pm 1.24$ \\
\hline Age of Menopause & $48.09 \pm 3.57$ \\
\hline Age of first birth & $21.9 \pm 4.53$ \\
\hline $\begin{array}{l}\text { The age of relatives when diagnosed with breast } \\
\text { cancer }\end{array}$ & $48.81 \pm 11.47$ \\
\hline
\end{tabular}

\section{RESULTS}

One hundred and seventy-seven female patients' relatives participated in the study. The ages of the women included in the sample group ranged between 18 and 79. Sociodemographic characteristics of the participants were given in Table 1.

Sixty six (37.30\%) of women were primary school graduates, 106 (59.90\%) were housewives, 124 (70.10\%) were married and 122 (68.90\%) had children. The other features about education, profession, income status and marital status were stated in Table 2.

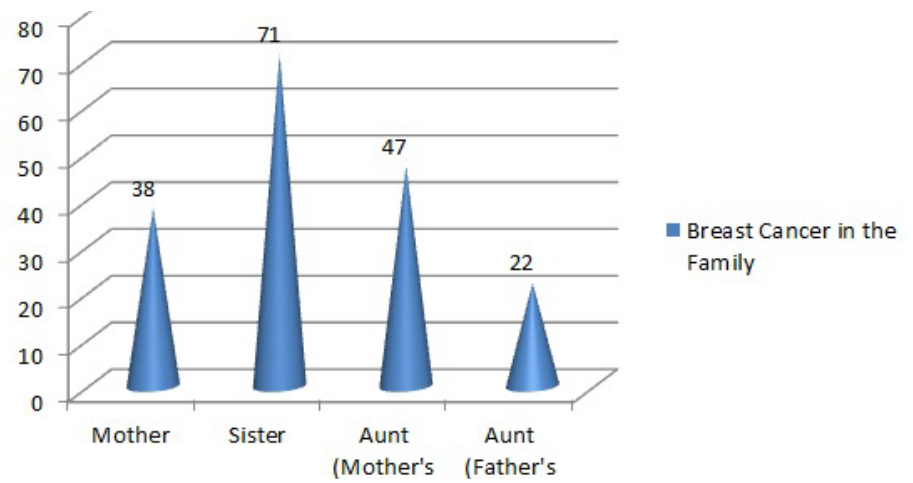

Figure 1. Breast Cancer Distribution in the Family of the Participants

When we look at the status of breast cancer in the family of the participants, most of the siblings who had breast cancer from their siblings were present (Figure 1).One hundred and twenty one (68.40\%) of women knew breast cancer screening methods, 46 (26\%) knew breast ultrasonography (USG) and 96 (54.20\%) knew MG. The number of participants who had breast cancer screening was 78 (44.10\%).

Of those undergoing breast cancer screening, 57 (32.20\%) had BSE, 22 (12.40\%) had breast USG and 43 (24.30\%) had MG (Figure 2).

Reasons for not being screened were given in Table 3.

\section{Breast Cancer Screening}

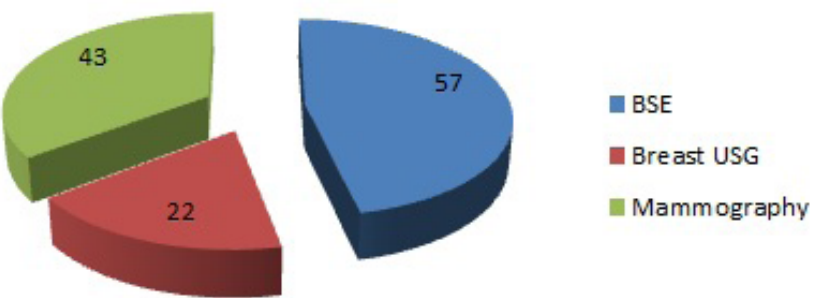

Figure 2. Distribution of the Methods Applied in Breast Cancer Screeners

Table 2. Distribution of Introductory Information of Women (n: 177).

\begin{tabular}{|l|c|}
\multicolumn{1}{c|}{ Features } & Number (\%) \\
\hline \multicolumn{1}{|c|}{ Education Status } \\
\hline literate & \\
\hline Illiterate & $19(10.7 \%)$ \\
\hline Primary education & $9(5.1 \%)$ \\
\hline High school & $66(37.3 \%)$ \\
\hline University & $39(22 \%)$ \\
\hline & $44(24.9 \%)$ \\
\hline Retired & \\
\hline Housewife & $6(3.4 \%)$ \\
\hline Self-employment & $106(59.9 \%)$ \\
\hline 0fficer & $5(2.8 \%)$ \\
\hline Health employee & $12(6.8 \%)$ \\
\hline Other & $8(4.5 \%)$ \\
\hline & $40(22.6 \%)$ \\
\hline Income less than expenses & \\
\hline Income and expense are equal & $114(64.4 \%)$ \\
\hline Income more than expenses & $50(28.2 \%)$ \\
\hline Marital status & $13(7.3 \%)$ \\
\hline The married & \\
\hline Single & $124(70.1 \%)$ \\
\hline Other & $50(28.2 \%)$ \\
\hline
\end{tabular}


Table 3. Reasons for not Sereening

\begin{tabular}{|l|c|}
\hline \multicolumn{1}{|c|}{ Reason } & Number/Ratio \\
\hline Ignorance & $47(26.6 \%)$ \\
\hline Do not be afraid of the result & $19(10.7 \%)$ \\
\hline Discomfort of the application & $15(8.5 \%)$ \\
\hline Not seeing yourself at risk & $35(19.8 \%)$ \\
\hline Lack of time & $11(6.2 \%)$ \\
\hline Accessibility to health services & $10(5.6 \%)$ \\
\hline Not relying on screening tests & $2(1.1 \%)$ \\
\hline Monetary deficiency & $4(2.3 \%)$ \\
\hline
\end{tabular}

In the last year, 38 (21.50\%) of those who applied to the doctor for information were found. 34 of them (19.20\%) followed the advice given by the physician. The participants' information needs importance mean averages $3.50 \pm 0.09$ and support needs importance averages $3.30 \pm 0.18$ were found. Participants' overall level of information needs meeting were found to be average scores of $2.18 \pm 0.15$ and support needs meeting were found to be average scores of $1.92 \pm 0.20$.

Information requirement items specified by the participants as very important; "Information about the causes of breast cancer" in the first place (3.66 \pm 0.64$)$, "Information about the risk of my own breast cancer" in the second place (3.60 \pm 0.79 ), "Information about the changes I can make in my health habits to reduce my risk of having breast cancer" (3.60 \pm 0.69$)$ and "information about what I can do to reduce the pain suffered by my relatives with breast cancer" (3.60 \pm $0.65)$ (Table 4). The first two items, which are crucially important for women among the support need items, are "having someone I can discuss my concerns about my relatives with breast cancer" (3.46 \pm 0.84 ) and "supporting me to reduce my concerns about breast cancer" (3.46 \pm 0.88$)$ (Table 4).

The items that the participants stated that they were a bit met among the information requirements items were "giving information about breast examination and showing how it was done" $(2.43 \pm 1.12)$ and "what women who have recently been diagnosed with breast cancer can feel (eg fear, anger etc.) information" $(2.33 \pm 1.01)$. The information requirements item they stated were never met, "information about genetic counseling for myself and my children" and "information about my daughter's risk of getting breast cancer" (Table 5). Among the support requirements items, the items that are stated to be a bit met are "having someone I can talk about with my concerns about breast cancer" (2.20 \pm 1.06$)$, "supporting me to reduce my concerns about breast cancer" (2.09 $\pm 1.16)$ and "supporting me to cope with my concerns about my family's disease" (2.08 \pm 1.08$)$. The support requirement items that they stated that they were never met were "I do not join a group that will support me", "remind me of mammography appointments" and "remind me of BSE" (Table 5).

\section{DISCUSSION}

This study is an important study to determine the information and support needs of the relatives of breast cancer patients and to what extent they are met. Mortality and morbidity of the disease can be reduced with early diagnosis of breast cancer screening programs (1).

When we look at the literature, there are studies on this subject. When we look at the study of Gencturk that the relatives of women with breast cancer examine their intimacy, it is found that there are breast cancer at equal rates of $43.80 \%$ (6). In a study by Chalmers et al. $64 \%$ of women were found to have breast cancer (10).

Through literature search it was found that BSE rates were similar. In the study conducted by Uzun et al. about the information of nursing students about BSE, it was determined that $31 \%$ of the participants performed BSE regularly (11). In the study conducted by Karayurt et al. with 100 participants, BSE rate was found to be $32 \%$ (12). In another study conducted with university students the rate of BSE was found to be $47.70 \%(13)$.

In previous studies the reasons for not having breast cancer screening were asked and participants stated that they did not get it due to lack of information with the highest rate $(1,11,14)$. This was in line with our findings We think that the lack of information about screening is high due to the low level of education of the participants in this study.

In the research of Guzel et al. about determining the knowledge of women about the early diagnosis methods of breast cancer, women gave the answer that they knew the breast examination the most (15). These findings are in line with our research results.

In the study of Chalmers et al. using the same scale in Canada, the top three information requirement importance items that women stated as very important; It was found as "giving information about breast examination and showing how it is done", "regularly examining my breasts by a healthcare professional who is knowledgeable about the subject" and "information about MG screening" (10). In the study of determining the information, support and needs of women with first degree relatives of breast cancer by Andic, the information requirement items that are stated as very important by women are "information about the treatment of breast cancer", and the three items in the second place are; "Information about the causes of breast cancer", "Information about the conditions that cause the risk of developing breast cancer", "Giving information about breast examination and showing how it is done" (15). Tunin et al. performed with the same scale in 2010, the first three information requirement importance items, which were stated as very important by 
women; "Information about MG screening", "Information about my own risk of breast cancer", "Information about the causes of breast cancer" (16). In this study, the first three items about information needs are "information about the causes of breast cancer". It was found as "information about the risk of myself becoming breast cancer" and "information about the changes I can make to my health habits to reduce my risk of having breast cancer."
In Chalmers et al.'s study, the importance of support requirement items that women stated as "very important, regularly examine my breasts by a healthcare professional who is knowledgeable about the subject", "while learning to perform a BSE, a healthcare professional knowledgeable about the subject is watching me and checking if I am doing it correctly and "supporting me to regularly perform a BSE" (10). In Andic's study the item, which is mentioned as very important among the support requirement items, is that "a healthcare

\section{Table 4. Item Scores Averages of the Importance of Information and Support Requirements Scale}

\begin{tabular}{|c|c|c|}
\hline Item & The Importance of Requirements & Mean \pm SD \\
\hline 2 & Information about the causes of breast cancer & $3.66 \pm 0.64$ \\
\hline 7 & Information about my own risk of getting breast cancer & $3.60 \pm 0.79$ \\
\hline 11 & Information about the changes I can make to my health habits to reduce my risk of having breast cancer & $3.60 \pm 0.69$ \\
\hline 12 & Information about what I can do to reduce the pain (sadness) experienced by my relatives with breast cancer & $3.60 \pm 0.65$ \\
\hline 14 & Information about conditions that create the risk of developing breast cancer (eg high-fat diet. hormone supportive therapy. etc.) & $3.57 \pm 0.75$ \\
\hline 3 & Information about the treatment of breast cancer (eg surgery. radiotherapy. chemotherapy. hormone therapy. side effects etc.) & $3.55 \pm 0.81$ \\
\hline 1 & Information on how to talk to my relatives with breast cancer about their lives & $3.55 \pm 0.75$ \\
\hline 4 & Information about how women who have been diagnosed with breast cancer can feel (eg fear. anger etc.) & $3.51 \pm 0.78$ \\
\hline 5 & Information about how women treated for breast cancer can feel (eg fear. anger. etc.) and physical symptoms of the disease & $3.51 \pm 0.75$ \\
\hline 13 & Information on how I can support my relatives with breast cancer & $3.47 \pm 0.80$ \\
\hline 9 & Information about my daughter's risk of getting breast cancer & $3.46 \pm 1.05$ \\
\hline 15 & Giving information about breast examination and showing how it is done & $3.46 \pm 0.96$ \\
\hline 17 & Information about how I should change my behavior to be healthier & $3.44 \pm 0.89$ \\
\hline 8 & Information on how to talk to my family about my risk of having breast cancer & $3.44 \pm 0.83$ \\
\hline 10 & Information on how to talk to my children about their risk of getting breast cancer & $3.42 \pm 1.03$ \\
\hline 16 & Information about mammography screening (breast film) (eg: how often should I do) & $3.41 \pm 0.96$ \\
\hline 6 & Information on how to talk to my family (spouse. children. siblings. etc.) about my relatives with breast cancer. & $3.38 \pm 0.91$ \\
\hline 18 & Information on genetic counseling for myself and my children & $3.31 \pm 1.01$ \\
\hline 29 & * Supporting me to reduce my concerns about breast cancer & $3.46 \pm 0.88$ \\
\hline 25 & *I have someone to talk about my concerns about my breast cancer & $3.46 \pm 0.84$ \\
\hline 23 & * Supporting me to deal with my concerns about my relative's disease & $3.45 \pm 0.95$ \\
\hline 28 & * Helping me to make a plan that I can apply if I get breast cancer one day in the future & $3.42 \pm 0.95$ \\
\hline 22 & * Supporting me to do breast self-examination on a regular basis & $3.41 \pm 0.98$ \\
\hline 27 & * Supporting me to cope with my feelings about my risk of getting breast cancer & $3.34 \pm 0.96$ \\
\hline 21 & * Regular examination of my breasts by a healthcare professional with knowledge of the subject (eg doctor. nurse etc.) & $3.26 \pm 1.13$ \\
\hline 24 & $\begin{array}{l}\text { * While learning to perform a breast self-examination. a knowledgeable healthcare professional will monitor me and check if I am doing } \\
\text { it correctly. }\end{array}$ & $3.26 \pm 1.13$ \\
\hline 19 & * Reminding me of my mammography (breast film) appointments (wire etc.) & $3.2 \pm 1.1$ \\
\hline 20 & * Reminding me to do my breast self-examination (wire etc.) & $3.16 \pm 1.12$ \\
\hline 26 & *I do not join a group that can support me & $2.84 \pm 1.36$ \\
\hline
\end{tabular}

* Support requirement items 
personnel knowledgeable about the subject should monitor me and check whether I have done it correctly while learning to perform a breast examination", "if I become breast cancer one day, assisted" and "supporting me to regularly perform a BSE" (15). Similarly, Tunin stated that the first three items of support need importance, which are considered as very important by women; "Regular examination of my breasts by a healthcare professional who is knowledgeable about the subject", "while learning to perform a BSE, a health care professional knowledgeable about the subject should follow me and check if I am doing it correctly" and "I have someone to discuss my concerns about my relatives with breast

\section{Table 5. Information and Support Requirements Meeting Ranking}

\begin{tabular}{|c|c|c|}
\hline Item & Requirement Level & Mean \pm SD \\
\hline 15 & Giving information about breast examination and showing how it is done & $2.43 \pm 1.12$ \\
\hline 4 & Information about how women who have been diagnosed with breast cancer can feel (eg fear. anger etc.) & $2.33 \pm 1.01$ \\
\hline 13 & Information on how I can support my relatives with breast cancer & $2.32 \pm 0.99$ \\
\hline 12 & 12- Information on what I can do to reduce the pain (sadness) experienced by my relatives with breast cancer. & $2.32 \pm 0.94$ \\
\hline 5 & $\begin{array}{l}\text { Information about how women treated for breast cancer can feel (eg fear. anger. etc.) and physical symptoms of the } \\
\text { disease }\end{array}$ & $2.30 \pm 1.03$ \\
\hline 1 & Information on how to talk to my relatives with breast cancer about their lives & $2.26 \pm 1.07$ \\
\hline 17 & Information about how I should change my behavior to be healthier & $2.26 \pm 1.02$ \\
\hline 7 & Information about my own risk of getting breast cancer & $2.24 \pm 1.15$ \\
\hline 16 & Information about mammography screening (breast film) (eg: how often should I do) & $2.21 \pm 1.15$ \\
\hline 11 & Information about the changes I can make to my health habits to reduce my risk of having breast cancer & $2.19 \pm 1.11$ \\
\hline 3 & $\begin{array}{l}\text { Information about the treatment of breast cancer (eg surgery. radiotherapy. chemotherapy. hormone therapy. side effects } \\
\text { etc.) }\end{array}$ & $2.19 \pm 1.00$ \\
\hline 6 & Information on how to talk to my family (spouse. children. siblings. etc.) about my relatives with breast cancer. & $2.16 \pm 1.14$ \\
\hline 14 & $\begin{array}{l}\text { Information about conditions that create the risk of developing breast cancer (eg high-fat diet. hormone supportive } \\
\text { therapy. etc.) }\end{array}$ & $2.15 \pm 1.16$ \\
\hline 8 & Information on how to talk to my family about my risk of having breast cancer & $2.08 \pm 1.14$ \\
\hline 2 & Information about the causes of breast cancer & $2.09 \pm 1.00$ \\
\hline 10 & Information on how to talk to my children about their risk of getting breast cancer & $2.00 \pm 1.15$ \\
\hline 9 & Information about my daughter's risk of getting breast cancer & $1.99 \pm 1.18$ \\
\hline 18 & Information on genetic counseling for myself and my children & $1.79 \pm 1.14$ \\
\hline 25 & *I have someone to talk about my concerns about my breast cancer & $2.20 \pm 1.06$ \\
\hline 29 & * Supporting me to reduce my concerns about breast cancer & $2.09 \pm 1.16$ \\
\hline 23 & * Supporting me to deal with my concerns about my relative's disease & $2.08 \pm 1.08$ \\
\hline 22 & * Supporting me to do breast self-examination on a regular basis & $2.05 \pm 1.14$ \\
\hline 27 & * Supporting me to cope with my feelings about my risk of getting breast cancer & $2.03 \pm 1.08$ \\
\hline 28 & * Helping me to make a plan that I can apply if I get breast cancer one day in the future & $1.95 \pm 1.14$ \\
\hline 21 & * Regular examination of my breasts by a healthcare professional with knowledge of the subject (eg doctor. nurse etc.) & $1.93 \pm 1.14$ \\
\hline 24 & $\begin{array}{l}\text { * While learning to perform a breast self-examination. a knowledgeable healthcare professional will monitor me and } \\
\text { check if I am doing it correctly. }\end{array}$ & $1.83 \pm 1.14$ \\
\hline 19 & * Reminding me of my mammography (breast film) appointments (by mail or phone) & $1.75 \pm 1.18$ \\
\hline 20 & * Reminding me to do my breast self-examination (by mail or phone) & $1.72 \pm 1.08$ \\
\hline 26 & * I do not join a group that can support me & $1.50 \pm 1.10$ \\
\hline
\end{tabular}


cancer" (16). In this study, "supporting me to reduce my concerns about breast cancer" was found to be very important as the support requirement items for the participants, since we made it to patients with breast cancer in their family.

In the study conducted by Chalmers et al., the first three information requirement items that women reported to be fully satisfied were "Giving information about BSE and showing how it is done", "information about mammography screening" and "information about how I should change my behavior to be healthier" (10). In Andic's study, the first three items that they stated that the information requirements were met were completely met; It has been found that there is "information about the treatment of breast cancer", "information about MG screening" and "information about the risk of myself becoming breast cancer (15). Tunin et al. stated that the first three information requirements that the women reported to be fully satisfied were met: "Information about MG screening", "information about my own risk of breast cancer" and "information about the causes of breast cancer" (16).

The first three support requirement items which were reported as fully met by women were stated in Chalmer's, Andic's and Tunin's study.

In Chalmer's study the first three support requirement items that women reported to be fully met were; "Regular examination of my breasts by a healthcare professional who is knowledgeable about the subject", "Supporting me to do the BSE regularly" and "A health care professional knowledgeable about the subject while monitoring my BSE and checking if I am doing it correctly" (10). In Andic's study the first three support requirement items that women reported to be fully met were; "Supporting me to reduce my concerns about breast cancer", "supporting me to cope with my feelings about my risk of getting breast cancer" and "supporting me to have regular BSE " (15).In Tunin's study the support requirement items were; "Regular examination of my breasts by a healthcare professional who is knowledgeable about the subject", "reminding me of my MG appointments" and "checking the self-examination of a knowledgeable healthcare staff while learning to perform a self-examination" and checking if I am doing it correctly (16). In this study the first three support requirement items are; information about the causes of breast cancer, information about my own risk of getting breast cancer and information about the changes I can make to my health habits to reduce my risk of having breast cancer. The findings show that the participants in this study had less knowledge about breast cancer. They needed to know reasons and risks. Unlike studies in the literature the desire to learn BSE was not stated as priority.

This study has several limitations. The study was conducted as cross-sectional study in one city's university hospital and this creates limitation of the generalization of our findings to Turkey. Second quantitative method and a scale was used for assessing the attitudes of patients' relatives. Besides adding qualitative method could be provide more information about beliefs and attitudes.

\section{CONCLUSION}

In conclusion, the issues that women stated as very important in terms of their information needs; The causes of breast cancer have been identified as information about the risk of breast cancer itself and the changes it can make in health habits in order to reduce the risk of breast cancer. The support need issues that women stated as very important are; He has been found to be concerned about breast cancer and about himself and his relative. It was found that the information requirements regarding the reminder of women joining the group to support them and performing BSE were not met at all. Health professionals are advised to provide information to women with breast cancer near the causes of breast cancer, screening methods, treatment methods, and prevention from breast cancer. It is recommended to perform self-examination or remind mammography appointments when necessary. Also it is needed to organize trainings to meet the information and support needs of women with breast cancer.

\section{ACKNOWLEDGEMENT}

\section{Peer-Review}

Externally Peer Reviewed

Conflict of Interest

The authors declare that they have no conflict of interests regarding content of this article..

Financial Support

The Authors report no financial support regarding content of this article.

\section{Ethical Declaration}

Ethical approval was obtained from Mustafa Kemal University Clinical Research Ethical Committee with date 02/05/2019 and number 05, and Helsinki Declaration rules were followed to conduct this study.

\section{REFERENCES}

1. Sohbet R, Karasu F. Kadınların meme kanserine yönelik bilgi, davranış ve uygulamalarının incelenmesi. Gümüşhane Üniversitesi Sağık Bilimleri Dergisi. 2017;6(4):113-21.

2. Torre L, Bray F, Siegel R, Ferlay J, Lortet-Tieulent J, Jemal A. Global cancer statistics, 2012 CA Cancer J Clin 2015;2015(65):87108. https://doi.org/10.3322/caac.21262

3. Siegel RL, Miller KD, Jemal A. Cancer statistics, 2019. CA: a cancer journal for clinicians. 2019;69(1):7-34. https://doi. org/10.3322/caac.21551

4. WHO. IARC. Globocan 2018. Estimated number of new cases in 2018. 
5. Anderson BO, Yip CH, Smith RA, Shyyan R, Sener SF, Eniu $A$, et al. Guideline implementation for breast healthcare in low-income and middle-income countries: overview of the Breast Health Global Initiative Global Summit 2007. Cancer. 2008;113(8 Suppl):2221-43. https://doi.org/10.1002/ cncr.23844

6. Gençtürk N, Akyolcu N. Meme Kanserli Kadınların, Birinci Derece Akrabalarının Bilgi Arama Davranışlarının Değerlendirilmesi ve Bilgi Gereksinimlerinin Giderilmesinde Eğitimin Etkinliği. Florence Nightingale Hemşirelik Dergisi. 2004;13(55):1-20.

7. Gross RE. Breast cancer: risk factors, screening, and prevention. Semin Oncol Nurs. 2000;16(3):176-84. https://doi. org/10.1053/sonc.2000.8110

8. Halk Sağlığı Genel Müdürlüğü Kanser Dairesi Bașkanlığı HSGMKD. https://hsgm.saglik.gov.tr/tr/kanser-taramastandartlari/listesi/meme-kanseri-tarama-program\%C4\%B1ulusal-standartlar\%C4\%B1.html

9. Chalmers KI, Luker KA, Leinster SJ, Ellis I, Booth K. Information and support needs of women with primary relatives with breast cancer: development of the Information and Support Needs Questionnaire. J Adv Nurs. 2001;35(4):497-507. https:// doi.org/10.1046/j.1365-2648.2001.01866.x

10. Chalmers K, Marles S, Tataryn D, Scott-Findlay S, Serfas K. Reports of information and support needs of daughters and sisters of women with breast cancer. Eur J Cancer Care (Engl). 2003;12(1):81-90. https://doi.org/10.1046/j.13652354.2003.00330.x
11. Uzun Ö, Karabulut N, Karaman Z. Hemşirelik Öğrencilerinin Kendi Kendine Meme Muayenesi ile Illgili Bilgi ve Uygulamaları. Anadolu Hemșirelik ve Sağlık Bilimleri Dergisi. 2004;7(1).

12. Karayurt Ö, Coşkun A, Cerit K. Hemşirelerin Meme Kanseri ve Kendi Kendine Meme Muayenesine IIlişkin İnançları ve Uygulama Durumu. Meme Sagligi Dergisi/Journal of Breast Health. 2008;4(1).

13. Gölbaşı Z, Çetin R, Kalkan S, Durmuş T. Üniversite öğrencisi kızların meme kanseri ve kendi kendine meme muayenesi ile ilgili bilgi ve davranıșları. Meme Sağlığı Dergisi. 2010;6(2):6973.

14. Güzel N, Bayraktar N. Kadınların Meme Kanserinin Erken Tanısına Yönelik Farkındalıklarının ve Uygulamalarının Belirlenmesi. Journal of Hacettepe University Faculty of Nursing. 2019;6(2).

15. Andıç S. Birinci derece yakınlarında meme kanseri olan kadınların bilgi ve destek gereksinimlerinin saptanması. Izmir: DEÜ Sağlık Bilimleri Enstitüsü; 2011.

16. Tunin R, Uziely B, Woloski-Wruble AC. First degree relatives of women with breast cancer: who's providing information and support and who'd they prefer. Psycho-Oncology. 2010;19(4):423-30. https://doi.org/10.1002/pon.1596 